illustrations leaves room for improvement in future issues.

\section{Library Science Abstracts}

THE first issue of a new quarterly journal, Library Science Abstracts, edited by Dr. C. B. Muriel Lock and Reginald Northwood Lock (1, No. 1, JanuaryMarch ; pp. 36 ; London: Library Association, 1950 ; 15s. a year), will be a disappointment to the scientific worker who may look to obtaining a summary of the latest papers on any particular science. The sub-title of the periodical is, however, more illuminating, for it reads, "A quarterly summary of articles of interest to Librarians and students of librarianship in the current periodical literature of the United Kingdom, the U.S.A., etc.". These abstracts will indeed be of service to professional librarians, and the need for such a publication is long overdue. Such periodicals as Adult Education, Library World and Unesco Bulletin for Libraries are covered by these abstracts, and subjects dealt with include public, hospital and special libraries, the art of the book, bibliography and bibliographies, and work with children.

\section{Bibliography of Science in Latin America}

Continding the sequence in the bibliography of Latin-American scientific activities (see Nature, April 15, p. 589), the Field Science Co-operation Office for Latin America, in collaboration with various Ibero-American organizations, has issued three lists : scientific institutions in Brazil ; scientific workers in Brazil; and scientific institutions of the Argentine ("Scientific Institutions and Scientists in Latin-America." Brazil : Vol. 1, pp. 139 ; Vol. 2, pp. 305. Argentina; Vol. 2, pp. 103. Montevideo: Unesco Centro de Conperación Cientifica para América Latina, 1950). These volumes are more than directories. The two lists on institutions give the date of foundation of each institution, indicate its functions and field of work, and contain information concerning staff and publications, a full list of the latter being supplied for some of the entries. The other volume on Brazil also supplies much fuller information than would be given in, say, "American Men of Science", a list of publications being included besides particulars of occupation, career and experience, special field of work and details of membership of scientific societies.

\section{Coryndon Memorial Museum, Nairobi}

THE annual report for 1949 of the Coryndon Memorial Museum, Nairobi (pp. 21. Nairobi : Coryndon Memorial Museum, 1950. 1s.), records a notable year because at long last an appral for funds to extend the Museum was lannched officially. This is for $£ 60,000, £ 50,000$ of which will be used for buildings and $£ 10,000$ for equipment and furnishings. The Government of Kenya has generously agreed to give $£ 5,000$ towards the appeal and, in addition, to grant a further $£ 1,000$ for every $£ 3,000$ subseribed by the public. It is hoped that the full amount will be raised by 1952; but meanwhile the Trustees have decided that the first part of the building programme was to commence in 1950. This part of the extensions will include halls for entomology, botany, fish and reptiles, while the later part envisages halls for prehistoric and modern man and for geology and palæontology. It is pleasing to note that additional research rooms and storage space are included in the plans.

\section{Announcements}

Prof. W. T. Astrury, professor of biomolecular structure in the University of Leeds, Prof. Harold Jeffreys, Plumian professor of astronomy in the University of Cambridge, and Prof. N. V. Sidgwick, formerly professor of chemistry in the University of Oxford, have been elected honorary life members of the New York Academy of Sciences.

Lifut-Colonel Francis J. Griffin, general secretary and editor-in-chief of the Society of Chemical Industry, has been invested with the Ordre de la Couronne de Chêne (Order of the Oaken Crown) of Luxembourg for his services to that country during and since the War. Col. Griffin was for many years registrar of the Royal Entomological Society of London, and was intimately concerned with the formation of the Society for the Bibliography of Natural History in 1936, acting for ten years as its honorary secretary and editor. He has been organizer of three recent international scientific conferences.

Tre National Research Council of Canada has announced the following new appointments in chemistry : Dr. Adrien Cambron, to be co-director, with Dr. E. W. R. Steacie, of the Division of Chemistry and director of the Applied Chemistry Branch, at the National Research Laboratories; Dr. Leo Marion to be assistant director of the Division of Chemistry and responsible, under Dr. Steacie, for the operation of the Pure Chemistry Branch.

Dr. M. C. Chang, of the Worcester Foundation for Experimental Biology, Shrewsbury, Massachusetts, has been appointed supervisor of the cattle ova transplantation programme of the Foundation of Applied Research, San Antonio, Texas. For more than eight years this Foundation, which is affiliated with the Southwest Research Institute at Essar Ranch, has been conducting research to enable low. grade cows to produce good-quality calves by acting as 'host mothers' to fertilized eggs transplanted from high-grade animals; so far pregnancies, but no births, have been obtained. Dr. Chang is a graduate of Tsing Hua University, Peking, and of the Universities of Edinburgh and Cambridge.

TrE Institution of Naval Architects is offering during 1951 the following scholarships for naval architecture to British subjects (age limit shown in brackets), which, except where otherwise stated, are worth $£ 175$ a year and must be applied for before May 31, 1951 : Elgar (23), for apprentices or pupils in the Royal dockyards or private shipyards (entries before January 15); Trewent (19), for apprentices or pupils in private shipyards ; Vickers-A rmstrongs (23), for apprentices or pupils in private shipyards ( $£ 220$ a year); Denny (19), tenable for four years at the University of Glasgow, with apprenticeship of five years. 'There is a similar Denny scholarship in marine engineering. Further particulars can be obtained from the secretary of the Institution of Naval Architects, 10 Upper Belgrave Street, London, S.W.1.

THE suggestion has been put forward that there is a need for a journal dealing entirely with the use and analysis of words and terminology in science and also in popular and even literary fields. It may be possible to start issuing a small mimeographed monthly or quarterly bulletin on this topic at the price of a shilling or two per copy to cover expenses; any suggestions or comments should be addressed to W. R. Dunlop, 57 Gordon Square, London, W.C.1. 